\title{
Livestock Forage Conditioning Among Six Northern Great Basin Grasses
}

\author{
Dave Ganskopp, ${ }^{1}$ Lisa Aguilera, ${ }^{2}$ and Marty Vavra $^{3}$ \\ Authors are ${ }^{1}$ Rangeland Scientist, United States Department of Agriculture-Agricultural Research Service, \\ Eastern Oregon Agriculture Research Center, 67826-A Highway 205, Burns, OR 97720; \\ ${ }^{2}$ Research Assistant, College of Veterinary Medicine, Oregon State University, Corvallis, OR 97331; and \\ ${ }^{3}$ Team Leader, Forestry and Range Science Laboratory, Pacific Northwest Research Station-Forest Service, \\ 1401 Gekeler Lane, La Grande, OR 97850.
}

\begin{abstract}
Studies of Anderson and Scherzinger's forage conditioning hypothesis have generated varied results. Our objectives were: 1 ) to evaluate late summer/early fall forage quality of crested wheatgrass (Agropyron desertorum [Fisch. ex Link] J. A. Schultes), bluebunch wheatgrass (Pseudoroegneria spicata [Pursh] A. Löve), Idaho fescue (Festuca idahoensis Elmer), bottlebrush squirreltail (Elymus elymoides [Raf.] Swezey), Thurber's needlegrass (Achnatherum thurberianum [Piper] Barkworth), and basin wildrye (Leymus cinereus [Scribn. \& Merr.] A. Löve) from ungrazed paddocks and paddocks grazed at vegetative, boot, and anthesis; and 2) test hypotheses that postgrazing regrowth yields were correlated with soil moisture content when grazing occurred. Crop-year precipitation for 1997 and 1998 was 134\% and 205\% of average. Crude protein (CP) and in vitro dry matter digestibility (IVDMD) of ungrazed grasses displayed expected declines in quality. Among ungrazed grasses, late summer/ early fall CP was $5.7 \%$ in 1997 and $3.6 \%$ in 1998 ; IVDMD was $47 \%$ and $41 \%$, respectively. Late summer/early fall forage quality was elevated by vegetative, boot stage, or anthesis grazing. The phenologically youngest regrowth always ranked highest in CP and IVDMD. Among grasses, respective 1997 CP and IVDMD means were $9.0 \%$ and $55 \%$ for regrowth following anthesis grazing. No regrowth followed anthesis grazing in 1998, but CP and IVDMD means from boot stage treatments were $5.5 \%$ and $47 \%$, respectively. With CP measures, a species by treatment interaction occurred in 1997, but species reacted similarly in 1998. Vegetative, boot stage, and anthesis grazing in 1997 caused respective late summer/early fall standing crop reductions of $34 \%, 42 \%$, and $58 \%$; and $34 \%, 54 \%$, and $100 \%$ reductions in 1998 . Forage conditioning responses were lower for bluebunch wheatgrass and crested wheatgrass than other grasses. Soil moisture content was a poor predictor of regrowth yields. Managed cattle grazing can successfully enhance late season forage quality.
\end{abstract}

\section{Resumen}

Los estudios sobre la hipótesis de acondicionamiento del forraje de Anderson y Scherzinger de 1975 han generado resultados variables. Nuestros objetivos fueron: 1) evaluar la calidad del forraje a fines de verano/inicios de otoño de los zacates "Crested wheatgrass" (Agropyron desertorum [Fischer ex Link] Schultes), "Bluebunch wheatgrass" (Psendoroegneria spicatum [Pursh] Scribn. \& Smith), "Idaho fescue" (Festuca idahoensis Elmer), "Bottlebrush squirreltail" Elymus elymoides [Raf.] Swezey), Thurber's needlegrass (Achnatherum thurberianum [Piper] Barkworth), y "Basin wildrye" (Leymus cinereus [Scribn. \& Merr.] A. Löve) en potreros sin apacentar y apacentados en las etapas fenológicas de crecimiento vegetativo, embuche, y antésis; y 2) probar la hipótesis de que los rendimientos del rebrote posterior al apacentamiento estaban correlacionados con el contenido de humedad del suelo cuando ocurrió el apacentamiento. La precipitación del año de cosecha en 1997 y 1998 fue 134\% y 205\% del promedio. La proteína cruda (CP) y la digestibilidad in vitro de la materia seca (IVDMD) de los zacates sin apacentar mostraron la disminución de calidad esperada. Entre los zacates sin apacentar, el contenido de $\mathrm{CP}$ a fines de verano/inicios de otoño fue de $5.7 \%$ en 1997 y $3.6 \%$ en 1998; la IVDMD fue de $47 \%$ y $41 \%$, respectivamente. La calidad del forraje a fines de verano/inicios de otoño fue mejorada por el apacentamiento en las etapas vegetativa, embuche, y antésis, y el rebrote de la etapa fenológica más temprana siempre tuvo el mayor contenido de CP y la mayor IVDMD. Entre los zacates, las medias respectivas de CP y IVDMD de 1997 fueron 9.0\% y 55\% para el rebrote del apacentamiento después de antesis. En 1998, no hubo rebrote después del apacentamiento en antesis, pero las medias de CP y IVDMD del tratamiento de apacentamiento en embuche fueron $5.5 \%$ y $47 \%$, respectivamente. En 1997, hubo interacción entre especies y tratamientos para la variable CP, pero en 1998 las especies reaccionaron en forma similar. En 1997, el apacentamiento en las etapas de crecimiento vegetativo, embuche, y antesis causaron una reducción de la biomasa a fines de verano/inicios de otoño de $34 \%, 42 \%$, y $58 \%$ respectivamente y de $34 \%, 54 \%$, y $100 \%$ en 1998. Las respuestas de acondicionamiento del forraje fueron menores para el "Bluebunch wheatgrass" y "Crested wheatgrass" que para las otras especies. El contenido de humedad del suelo fue pobre para

Eastern Oregon Agricultural Research Center is jointly operated by the Oregon Agricultural Experiment Station of Oregon State University and the United States Dept of AgricultureAgricultural Research Service.

Proprietary or trade names are for information only and do not convey endorsement of one product over another.

Correspondence: Dave Ganskopp, USDA-ARS, Eastern Oregon Agriculture Research Center, 67826-A Highway 205, Burns, OR 97720. Email: david.ganskopp@oregonstate.edu

Manuscript received 18 December 2005; manuscript accepted 28 September 2006. 
predecir los rendimientos del rebrote. El manejo del apacentamiento del ganado puede mejorar exitosamente la calidad del forraje a fines de la estación.

Key Words: diet quality, forage quality, grazing management, nutrition, wildlife habitat

\section{INTRODUCTION}

When studying effects of spring cattle grazing on crested wheatgrass (Agropyron desertorum [Fisch. ex Link] J. A. Schultes), Hyder and Sneva (1963) noted removal of elevated meristems stimulated growth of new tillers that cured before completing their reproductive phases of development. They speculated the resulting cured but leafy herbage provided palatable and more nutritious late-summer or fall forage than nutritionally deficient deferred stands of grass (Hyder and Sneva 1963). Wildlife are often attracted to high quality forages, and Anderson and Scherzinger (1975) speculated a more than 4-fold increase in wintering elk (Cervus elaphus nelsoni Bailey) in central Oregon was stimulated by managed spring cattle grazing that elevated fall and winter forage quality and palatability. Research in Washington, however, suggested spring grazing might not always stimulate additional use by wildlife (Skovlin et al. 1983). Although none of these studies quantified the nutritional character of herbage, their basic premise of forage conditioning became a widespread component of grazing management programs (Pitt 1986).

Several studies have further explored the forage conditioning hypothesis via clipping with mixed results. Some report nutritional gains as indexed by CP measures from spring defoliations of bluebunch wheatgrass (Pseudoroegneria spicata [Pursh] A. Löve ssp. spicata) (Pitt 1986; Clark et al. 1998), but others found no increase in fall nutritional value (WestenskowWall et al. 1994; Wambolt et al. 1997). Clark et al. (2000) applied boot-stage sheep grazing to bluebunch wheatgrass and Idaho fescue (Festuca idahoensis Elmer) and elevated November CP levels by $1 \%$ and $1.3 \%$, respectively. In vitro dry matter digestibility (IVDMD) of bluebunch wheatgrass was increased by $4.3 \%$ (Clark et al. 2000). Similarly, grazing by elk elevated live/dead ratios of spring forage and caused a slight but significant increase in nitrogen content and digestibility (Hobbs et al. 1996). Digestibility and fiber content of actual cattle diets, however, did not change with elk grazing (Hobbs et al. 1996). More recently, light and heavy spring grazing applications elevated fall and winter crude protein content and digestibility among bluebunch wheatgrass, Idaho fescue, and bottlebrush squirreltail (Elymus elymoides [Raf.] Swezey spp. elymoides) (Ganskopp et al. 2004). Heavy grazing treatments were most successful at conditioning forages, but they reduced fall standing crop by up to $67 \%$ (Ganskopp et al. 2004).

Given these varied results and their limited array of species, we designed a study to investigate the forage conditioning hypothesis with cattle grazing among 6 of the northern Great Basin's most prominent rangeland grasses. Our objectives were: 1) to evaluate late summer and early fall nutritional characteristics of crested wheatgrass, bluebunch wheatgrass, Idaho fescue, bottlebrush squirreltail, Thurber's needlegrass (Achnatherum thurberianum [Piper] Barkworth), and basin wildrye (Leymus cinereus [Scribn. \& Merr.] A. Löve) in un- grazed paddocks and paddocks grazed by cattle at vegetative, boot, and anthesis stages of growth; and 2) explore hypotheses that postgrazing regrowth yields from these grasses were correlated with available soil moisture when paddocks were grazed by cattle.

\section{MATERIALS AND METHODS}

\section{Study Area and Paddocks}

Research was conducted on the Northern Great Basin Experimental Range (lat $43^{\circ} 28^{\prime} 48.3^{\prime \prime} \mathrm{N}$, long $119^{\circ} 42^{\prime} 32.2^{\prime \prime} \mathrm{W}$, elevation $1403 \mathrm{~m}$ ) near Burns, Oregon in 1997 and 1998. Mean annual precipitation at headquarters was $282 \mathrm{~mm}$. Average annual temperature was $7.6^{\circ} \mathrm{C}$ with historic extremes of $-31^{\circ}$ and $42^{\circ} \mathrm{C}$ (referenced as the Squaw Butte Experiment Station in NOAA [2003] records). Vegetation of the region is characterized by a dispersed western juniper (Juniperus occidentalis Hook.) overstory and a shrub layer dominated by either Wyoming big sagebrush (A. tridentata Nutt. ssp. wyomingensis Beetle and Young), little sagebrush (Artemisia arbuscula Nutt.), or mountain big sagebrush (A. tridentata Nutt. ssp. vaseyana [Rydb.] Beetle) listed in order of prominence. Major native grasses include: bluebunch wheatgrass, Idaho fescue, Sandberg's bluegrass (Poa secunda J. Presl), Thurber's needlegrass, and bottlebrush squirreltail. Nomenclature follows USDA, NRCS PLANTS database (2006).

Twelve study paddocks, bounded by electric fencing, were established in a 0.4 ha transplant garden described by Cruz and Ganskopp (1998). Transplanted tussocks were extracted from surrounding pastures in 1989, and the entire garden supported 900 specimens of each grass. Row/column spacing was $0.61 \mathrm{~m}$ between plant centers. Tussocks were arranged in a completely randomized fashion to prevent stock from selectively harvesting one species or another by grazing either a row or column. Each of the 12 paddocks supported approximately 75 tussocks of each species. Underlying soils were a complex of loam and loamy fine sands (Milican coarse-loamy, mixed, frigid Orthidic Durixerolls and Holtle coarse-loamy, mixed, frigid Aridic Duric Haploxerolls, respectively) (Lentz and Simonson 1986). Depth to bedrock or hardpan ranged from 90 to $150 \mathrm{~cm}$.

\section{Treatment Applications, Forage, and Soil Moisture Sampling}

Experimental design was a randomized complete block with 4 treatments dispersed among 4 paddocks within each of 3 blocks. The 4 treatments included 3 grazing applications and an ungrazed control across 6 species of grasses. For each grazing treatment, 2 steers were left in each paddock for up to 24 hours to reduce herbage to a $2.5-\mathrm{cm}$ stubble. Mean weight of the 6 Hereford $\times$ Angus steers was $287 \mathrm{~kg} \pm 13$ (mean $\pm \mathrm{SE}$ ) at the beginning of the 1997 trials and $281 \mathrm{~kg} \pm 17 \mathrm{SE}$ at the start of the 1998 trials. Grazing treatments occurred during vegetative (30 April 1997 and 5 May 1998), boot (14 May 1997 and 18 
May 1998), and anthesis (13 June 1997 and 29 June 1998) stages of phenology as indexed by bluebunch wheatgrass. Treatment assignments were rerandomized among paddocks the second year.

Before applying grazing treatments, samples of herbage were harvested to a $2.5-\mathrm{cm}$ stubble from a minimum of 3 randomly drawn individual tussocks of each species per paddock to quantify standing crop and seasonal forage quality. Clipped materials were placed in paper bags, oven dried at $60^{\circ} \mathrm{C}$, weighed on an analytical scale, ground to pass a $1-\mathrm{mm}$ mesh, and stored in plastic bags for later analyses. Physical measures of tussocks at all sampling periods included each plant's widest basal diameter and a second largest diameter perpendicular to the first. We solved for elliptical crown area and expressed herbage yields on a $\mathrm{g} \cdot \mathrm{cm}^{-1}$ basal area basis.

Soil moisture was sampled weekly in each paddock beginning on 15 April and ending on 15 September. Sample columns reached $30 \mathrm{~cm}$ with the top $5 \mathrm{~cm}$ discarded to reduce microenvironmental effects. Three other soil samples were sent to the Soil Physics Laboratory, Department of Crop and Soil Science, Oregon State University for development of moisture release curves. Moisture release curves were used to convert gravimetric measures of percent soil moisture to megapascal units (Mpa).

Counts of reproductive culms per tussock across all treatments and species were conducted on 31 July. These data were expected to index treatment effects on reproductive efforts of the grasses.

Lastly, regrowth from grazed treatments and standing crop from ungrazed controls were sampled to a $2.5-\mathrm{cm}$ stubble on 31 July and again on 15 September. Herbage samples were handled as above. Yield data described grazing treatment effects on standing crop at mid-summer and early fall. Nutritional analyses of materials were used to describe the relative success of the forage conditioning treatments and to quantify an expected further decline in forage quality between midsummer and early fall.

\section{Forage Quality Assays}

Forage quality indices of pretreatment growth and regrowth were crude protein $(\mathrm{CP})$ and in vitro dry matter digestibility (IVDMD). Crude protein was defined as percent Kjeldahl nitrogen $\times 6.25$ (AOAC 1990), and IVDMD determinations followed Tilley and Terry (1963) modified for an ANKOM Daisy II Incubator.

\section{Statistical Analyses}

Pretreatment seasonal forage quality and yield dynamics (CP and IVDMD) were analyzed with a split-plot analysis of variance to assess species $(n=6)$, harvest date $(n=5)$, and species $\times$ harvest date effects. Species $(5 \mathrm{df})$ were whole plots, with the block $\times$ species interaction $(10 \mathrm{df})$ serving as error term 1 . Harvest dates $(4 \mathrm{df})$ were subplots, with harvest date and the species $\times$ harvest date interaction (20 df) tested with the residual error term ( $48 \mathrm{df}$ ). This approach was used because sequences in time can not be randomized, generating an inadvertent split plot (Peterson 1985; Cody and Smith 1997). Experiments from the 2 years were analyzed separately. Mean separations between adjacent harvest dates within a species were accomplished with Fisher's protected LSD procedures (Fisher 1966).

Herbage yields and forage quality samples of regrowth from the 4 grazing treatments ( 3 grazing periods and ungrazed controls) were sampled among all 6 grasses on 2 dates (31 July and 15 September). Analyses of these data employed a split-split-plot analysis of variance with species $(n=6)$ as whole-plots, grazing treatment or grazing date $(n=4)$ as subplots, and harvest date $(n=2)$ as sub-subplots. Species effects $(5 \mathrm{df})$ were tested with the block $\times$ species interaction (error $1,10 \mathrm{df})$. Treatment $(3 \mathrm{df})$ and species $\times$ treatment effects $(15 \mathrm{df})$ were tested with the block $\times$ species $\times$ treatment interaction (error 2, $36 \mathrm{df})$. Harvest date (1 df) and the species $\times$ harvest date $(5 \mathrm{df})$, treatment $\times$ harvest date $(3 \mathrm{df})$, and species $X$ treatment $\times$ harvest date $(15 \mathrm{df})$ effects were tested with the residual error term (error 3, $48 \mathrm{df}$ ). Individual years were analyzed separately. Again, a split-plot approach was employed because time series (grazing dates and harvest dates) can not be randomized, generating inadvertent split plots (Peterson 1985; Cody and Smith 1997). Mean separations employed Fisher's protected LSDs (Fisher 1966) with Satterthwaite's approximation for estimating degrees of freedom (Satterthwaite 1946).

Forward stepwise regression analyses were used to test hypotheses that end of growing season (15 July) regrowth yield of grasses was a product of soil moisture content when tussocks were initially grazed. Independent variables included soil moisture content $(\mathrm{Mpa})$ in raw and several exponential forms, and counts of days elapsed between treatment application and plant dormancy. In all but the wettest of years, herbage in the northern Great Basin has typically exploited available soil moisture by early to mid-July, whereupon aboveground portions of grasses wither and cure. The dependent variable was regrowth yield, expressed on a $\mathrm{g} \cdot \mathrm{cm}^{-2}$ basal area basis. Statistical significance in all analyses was accepted at $P \leq 0.05$, and all values following “ \pm ” symbols are SE.

\section{RESULTS}

\section{Precipitation Patterns and Treatment Applications}

Sneva (1982) found crop-year forage accumulations in the region most closely correlated with September-June precipitation accumulations. Crop-year precipitation sums for 1997 and 1998 were $134 \%$ and $205 \%$, respectively, of the long term mean (259 mm; NOAA 2003). A severe hailstorm on 11 June 1997 heavily damaged reproductive stems of grasses just as anthesis approached. Given the destructive effects of this storm, no statistical analyses were conducted on reproductive tiller counts.

Cattle successfully reduced stubble height to $2.5 \mathrm{~cm}$ or less in all grazing applications. Subsequently harvested forage, therefore, contained no pretreatment herbage and should reflect the grasses' full potential to generate high quality regrowth.

\section{Pretreatment Standing Crop and Forage Quality}

Analyses of pretreatment yields for both years showed harvest date was the only significant $(P \pm 0.03)$ effect. In 1997 , herbage accumulations progressed from $0.08_{\mathrm{a}} \pm 0.01 \mathrm{~g} \cdot \mathrm{m}^{-2}$ basal area for vegetative growth to $0.18 \mathrm{ab} \pm 0.02 \mathrm{~g} \cdot \mathrm{cm}^{-2}$ at the boot 

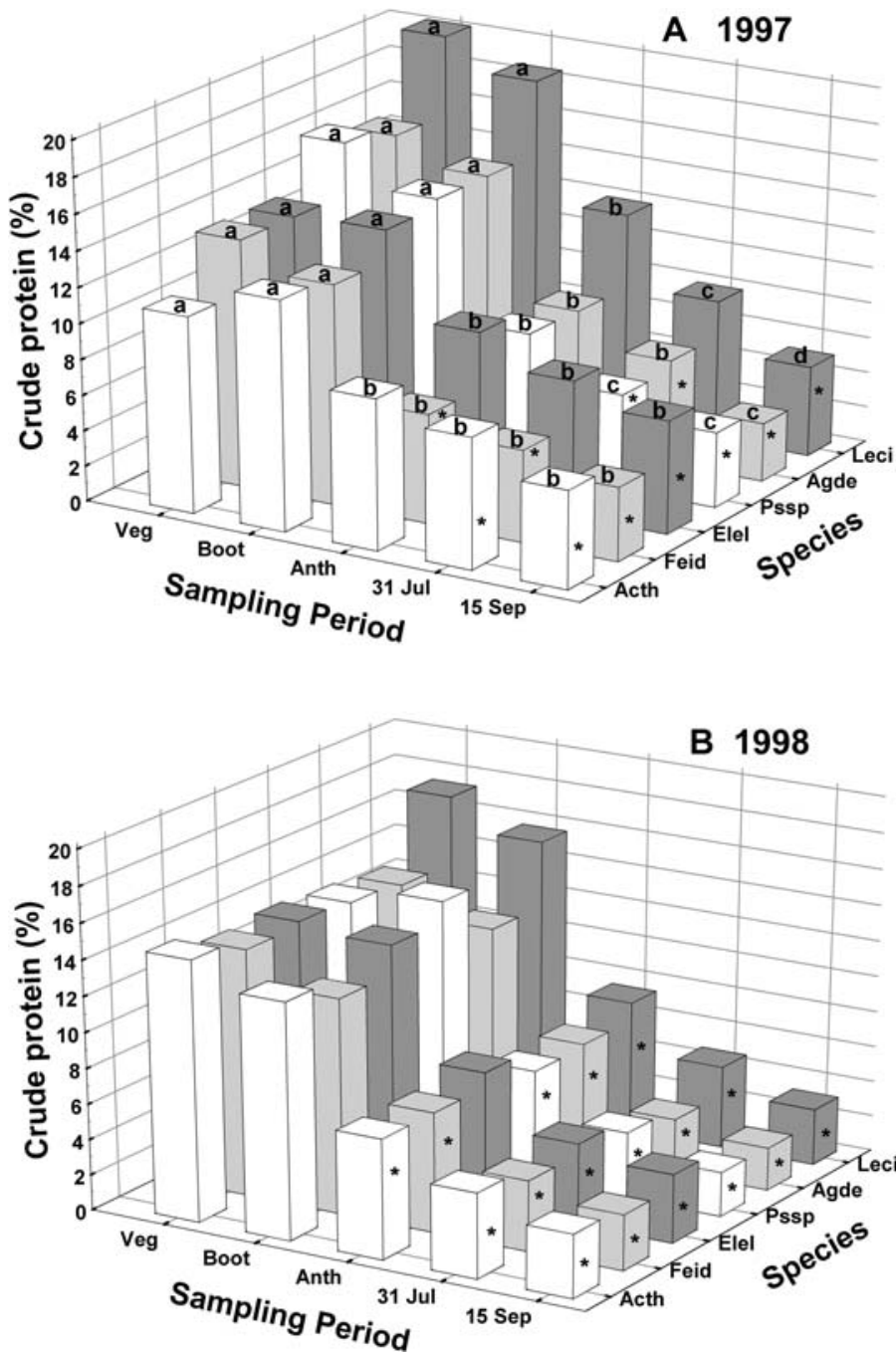

Figure 1. Seasonal crude protein of 6 grasses sampled at 3 stages of phenology (Veg $=$ vegetative, Boot, Anth $=$ anthesis) and 2 subsequent dates on the Northern Great Basin Experimental Range near Burns, OR, in 1997 (A) and 1998 (B). Species designations are: Acth = Thurber's needlegrass, Feid $=$ Idaho fescue, Elel $=$ bottlebrush squirreltail, Pssp $=$ bluebunch wheatgrass, Agde $=$ crested wheatgrass, and Leci $=$ giant wildrye. Adjacent means within a species (row) sharing a common letter are not significantly different $(P>0.05)$. Values of bars bearing an asterisk $\left({ }^{*}\right)$ are $<7.5 \%$ crude protein. Mean separations were not conducted within species for the 1998 (B) data because species and harvest date effects were the only significant components in analyses of variance $(P \leq 0.05)$.

stage, $0.29_{\mathrm{bc}} \pm 0.03 \mathrm{~g} \cdot \mathrm{cm}^{-2}$ at anthesis, and $0.36_{\mathrm{c}} \pm 0.11$ $\mathrm{g} \cdot \mathrm{cm}^{-2}$ when herbage was dormant on $15 \mathrm{July}$. As indicated by the subscripted lower case letters, values did not differ between adjacent sampling periods $(P>0.05)$ but separations occurred $(P<0.05)$ if a comparison spanned adjacent sampling periods. In 1998, vegetative, boot, anthesis, and 15 July herbage yields were $0.23_{\mathrm{a}} \pm 0.04,0.36_{\mathrm{ab}} \pm 0.05,0.44_{\mathrm{b}} \pm 0.08$, and $0.47_{\mathrm{b}} \pm$ $0.08 \mathrm{~g} \cdot \mathrm{cm}^{-2}$, respectively. Again, values sharing a common subscript are not significantly different $(P>0.05)$.

Analyses of 1997 crude protein concentration revealed significant $(P<0.01)$ species, sampling date, and species $\times$ sampling date effects. Given the significant interaction, means are presented in Figure 1A. All grasses exhibited the seasonal decline in CP concentration typical of ungrazed herbage in the northern Great Basin. Crude protein concentration of Thurber's needlegrass, Idaho fescue, bluebunch wheatgrass, and crested wheatgrass was reduced to less than $7.5 \%$ by 31 July. Crude protein of bottlebrush squirreltail and basin wild rye (the exceptions) were $7.6 \%$ and $7.9 \%$, respectively on 31 July. By 15 September, herbage from all 6 grasses contained less than $7.5 \%$ CP.

Analyses of 1997 IVDMD and 1998 CP and IVDMD generated consistent patterns with significant main effects (species and sampling dates $(P \leq 0.01)$ but no interactions $(P$ $>0.05)$. To maintain continuity with 1997 data, however, 1998 CP values are presented in 3-dimension form (Fig. 1B) but no mean separations were conducted within species. With the exception of bottlebrush squirreltail ( $\mathrm{CP}=7.6 \%$ ), CP content of all grasses declined more rapidly in 1998 than in 1997, and CP was below 7.5\% at anthesis for all grasses in 1998 .

\section{Regrowth Standing Crop}

Regrowth yields for 1997 exhibited significant species, grazing treatment, and species $\times$ grazing treatment effects. Species $\times$ grazing treatment means are found in Table 1. Basin wildrye was the only grass with consistent successive declines in regrowth yield as we advanced from vegetative through the more phenologically advanced boot and anthesis grazing treatments in 1997. Potentially, the June 1997 hailstorm had a greater effect on the more delicate herbage of the remaining 5 grasses than the more robust basin wildrye and that event might have confounded our regrowth yields. If one ignores the species $x$ treatment interaction and sums regrowth yields across species, the vegetative, boot, and anthesis treatments each respectively generated $34 \%, 42 \%$, and $58 \%$ reductions in pooled late summer/early fall standing crop when compared with ungrazed tussocks.

Analyses of regrowth yields for 1998 generated significant species and treatment main effects but no interactions. Among species, basin wild rye produced the greatest regrowth yield $\left(0.43 \mathrm{~g} \cdot \mathrm{cm}^{-2}\right.$ basal area) and Thurber's needlegrass, at $0.12 \mathrm{~g} \cdot \mathrm{cm}^{-2}$ basal area, the least (Table 1). Yields among the remaining 4 grasses were intermediate with some statistical overlap among means. Among treatment effects, grazing at the vegetative stage of phenology caused a $34 \%$ reduction in pooled late summer/early fall standing crop, whereas boot stage grazing reduced standing crop by 54\%. In 1998, none of the grasses grazed at anthesis generated measurable regrowth.

\section{Regrowth Crude Protein}

Regrowth CP content in 1997 displayed significant species, grazing treatment, and harvest date main effects, as well as significant species $\times$ grazing treatment and grazing treatment $\times$ harvest date interactions. Species $\times$ grazing treatment means are found in Figure 2 with separations focused on comparisons between the 3 grazed treatments and ungrazed herbage. For 2 grasses, Thurber's needlegrass and Idaho fescue, the CP content of regrowth from all 3 grazing treatments was significantly greater than ungrazed herbage. Thurber's needlegrass regrowth from all 3 grazed treatments also equaled or exceeded $7.5 \% \mathrm{CP}$ when harvested in late summer and early fall. No regrowth from Idaho fescue reached the $7.5 \%$ CP level. 
Table 1. Species $\times$ grazing treatment regrowth yields $( \pm S E)$ of 6 grasses on the Northern Great Basin Experimental Range near Burns, OR, that were either ungrazed or exposed to 3 seasonal cattle grazing treatments and harvested on 31 July and 15 September in 1997 as well as species and treatment main effect means for the same study repeated in 1998. The 1997 means within a row sharing a common letter are not significantly different $(P>0.05)$. Among the 1998 species listings, values within a column sharing a common letter are not significantly different $(P>0.05)$.

\begin{tabular}{|c|c|c|c|c|c|}
\hline \multirow[b]{2}{*}{ Species } & \multirow[b]{2}{*}{ Vegetative } & \multicolumn{3}{|c|}{1997} & \multirow{2}{*}{$\frac{1998}{\text { Species means }}$} \\
\hline & & Boot & Anthesis & Ungrazed & \\
\hline & \multicolumn{5}{|c|}{ 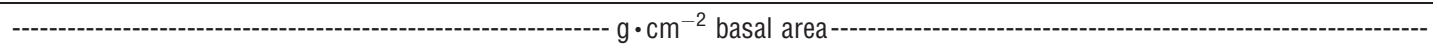 } \\
\hline Basin wildrye & $0.49 \pm 0.07 \mathrm{~b}$ & $0.38 \pm 0.08 \mathrm{ab}$ & $0.24 \pm 0.04 a$ & $0.95 \pm 0.35 c$ & $0.43 \pm 0.09 \mathrm{~d}$ \\
\hline Crested wheatgrass & $0.22 \pm 0.03 a$ & $0.15 \pm 0.02 \mathrm{a}$ & $0.08 \pm 0.03 a$ & $0.26 \pm 0.01 \mathrm{a}$ & $0.28 \pm 0.09 c$ \\
\hline Bluebunch wheatgrass & $0.23 \pm 0.05 a$ & $0.33 \pm 0.03 a$ & $0.15 \pm 0.03 a$ & $0.30 \pm 0.05 a$ & $0.28 \pm 0.07 c$ \\
\hline Bottlebrush squirreltail & $0.23 \pm 0.04 a$ & $0.17 \pm 0.03 a$ & $0.31 \pm 0.10 a$ & $0.27 \pm 0.06 a$ & $0.26 \pm 0.06 b c$ \\
\hline Idaho fescue & $0.13 \pm 0.01 a b$ & $0.13 \pm 0.01 a$ & $0.11 \pm 0.02 a$ & $0.34 \pm 0.06 b$ & $0.21 \pm 0.09 b$ \\
\hline \multirow[t]{2}{*}{ Thurber's needlegrass } & $0.25 \pm 0.10 a$ & $0.15 \pm 0.04 a$ & $0.12 \pm 0.04 a$ & $0.16 \pm 0.04 a$ & $0.12 \pm 0.03 a$ \\
\hline & & \multicolumn{3}{|c|}{1998} & \\
\hline Treatment means & $0.25 \pm 0.06 b$ & $0.17 \pm 0.03 a$ & - & $0.37+0.05 c$ & \\
\hline
\end{tabular}

With bottlebrush squirreltail, $\mathrm{CP}$ content of regrowth from the 2 latest grazing treatments $($ boot $=8.6 \%$ and anthesis $=$ $11.3 \% \mathrm{CP})$ exceeded that of ungrazed herbage $(7.0 \% \mathrm{CP})$. The $\mathrm{CP}$ content of regrowth, however, from all 3 grazed treatments equaled or exceeded $7.5 \%$ CP. Of the remaining 3 grasses (giant wildrye, bluebunch wheatgrass, and crested wheatgrass), only the anthesis grazing treatment generated regrowth with a $\mathrm{CP}$ content exceeding ungrazed herbage. With basin wildrye, regrowth from both the boot stage and anthesis treatments equaled or exceeded $7.5 \% \mathrm{CP}$, whereas crested and bluebunch wheatgrass were similarly affected by only the latest (anthesis) grazing treatment. Grazing treatment $\times$ harvest date means for 1997 are found in Table 2. Averaged across grazing treatments and species, herbage CP declined by about $2.6 \%$ between 31 July and 15 September. Crude protein of regrowth from boot stage and anthesis treatments declined by about 3\% from late July to mid-September. The relatively lower quality ungrazed and vegetatively grazed treatments experienced about a $2 \%$ deterioration over the same period. All comparisons between harvest dates within a grazing treatment were significantly different $(P<0.05)$. All separations between grazing treatments within a harvest date were significant on 31 July, but vegetative and boot stage grazing treatments were similar by mid September.

For regrowth CP content in 1998, only species main effects were significant. Nevertheless, species by sampling period means can be found in Figure 1B to provide continuity with data presented for 1997. Ranked species CP means and standard errors were: crested wheatgrass $3.8_{\mathrm{a}} \pm 0.2$, bluebunch wheatgrass $4.1_{\mathrm{ab}} \pm 0.3$, giant wildrye $4.5_{\mathrm{b}} \pm 0.3$, bottlebrush squirreltail $5.0_{c} \pm 0.3$, Idaho fescue $5.0_{c} \pm 0.4$, and Thurber's needlegrass $5.2_{\mathrm{c}} \pm 0.3$. Values sharing a common subscript were not significantly different $(P>0.05)$. Among species and grazing treatments, no regrowth was harvested in 1998 that equaled or exceeded $7.5 \%$ CP. Similar to 1997 findings, grazing treatment and harvest date exhibited a significant interaction (Table 2). Across treatments, CP declined by about $1.4 \%$ between 31 July and 15 September. Lower quality ungrazed herbage displayed about a 1 percentage point decline, whereas regrowth from the boot stage grazing treatment declined by $2 \%$. Intermediate-quality regrowth of the vegetatively grazed treatment declined by about $1.3 \%$ between the first and second sampling dates. All mean separations among grazing treatments within a harvest date were significant $(P<0.05)$.

\section{Regrowth In Vitro Dry Matter Digestibility (IVDMD)}

With one exception, a grazing treatment $\times$ harvest date interaction in 1998, patterns of significant effects were similar between years for digestibility of regrowth. In both years, species, grazing treatment, and harvest date main effects were

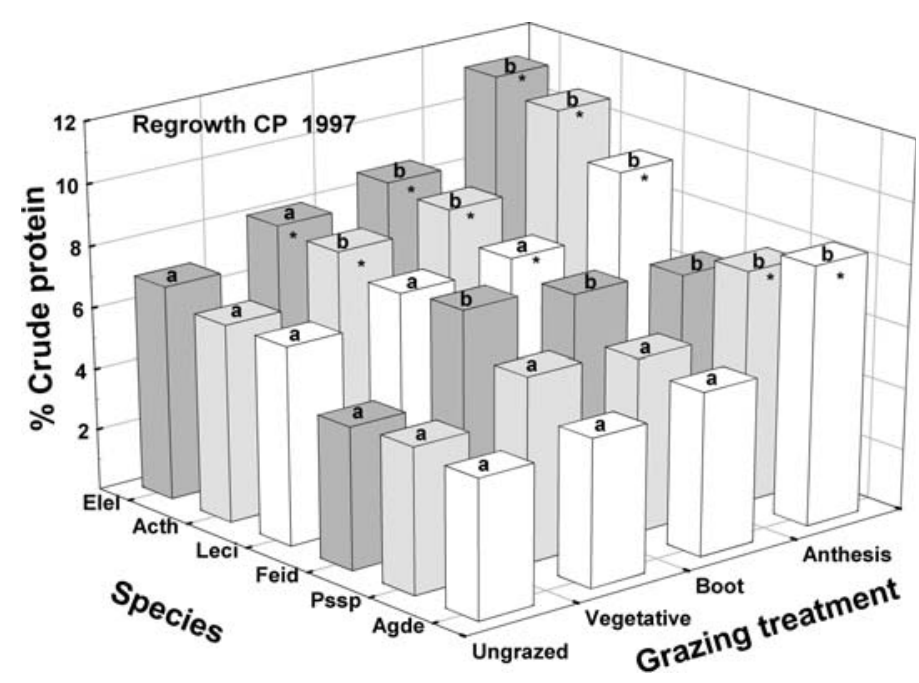

Figure 2. Pooled (late summer and early fall) mean crude protein content of herbage from 6 grasses that were either ungrazed or exposed to 1 of 3 possible growing season cattle grazing treatments on the Northern Great Basin Experimental Range near Burns, OR, in 1997. Species designations are: Acth $=$ Thurber's needlegrass, Feid $=$ Idaho fescue, Elel = bottlebrush squirreltail, Pssp = bluebunch wheatgrass, Agde $=$ crested wheatgrass, and Leci $=$ giant wildrye. Sampling period phenology abbreviations are: Veg $=$ vegetative and Anth $=$ anthesis. Lower case letters above each bar are for mean separation $(P \leq 0.05)$ between ungrazed herbage (the leftmost row) and either of the 3 grazed treatments within a species. Values of means containing an asterisk $\left({ }^{*}\right)$ are $\geq 7.5 \%$ crude protein. 
Table 2. Crude protein content $( \pm S E)$ of regrowth from 3 grazed treatments and ungrazed herbage averaged among 6 grasses sampled on 2 dates at the Northern Great Basin Experimental Range near Burns, OR, in 1997 and 1998. All comparisons between harvest dates within a grazing treatment and year are significantly $(P<0.05)$ different and mean separation indices are not shown. Treatment means within a year and sampling date (row) sharing a common letter are not significantly different $(P>0.05)$.

\begin{tabular}{|c|c|c|c|c|}
\hline \multirow[b]{2}{*}{ Harvest date } & \multirow[b]{2}{*}{ Ungrazed } & \multicolumn{3}{|c|}{ Grazing treatment } \\
\hline & & Vegetative & Boot stage & Anthesis \\
\hline & -------------' & 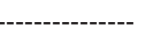 & \% -----------' & ---------------' \\
\hline 31 July 1997 & $6.6 \pm 0.3 a$ & $8.0 \pm 0.3 b$ & $8.7 \pm 0.5 c$ & $10.8 \pm 0.5 d$ \\
\hline 15 Sept. 1997 & $4.8 \pm 0.3 a$ & $5.9 \pm 0.3 a$ & $5.6 \pm 0.3 a$ & $7.3 \pm 0.5 b$ \\
\hline 31 July 1998 & $4.1 \pm 0.2 \mathrm{a}$ & $5.2 \pm 0.3 b$ & $6.5 \pm 0.2 c$ & - \\
\hline 15 Sept. 1998 & $3.1 \pm 0.2 \mathrm{a}$ & $3.9 \pm 0.1 b$ & $4.5 \pm 0.2 c$ & - \\
\hline
\end{tabular}

significant. Among 4 of the grasses (Idaho fescue, bluebunch wheatgrass, bottlebrush squirreltail, and Thurber's needlegrass), the relative rankings of digestibility were also similar (Table 3). In both years, regrowth of Idaho fescue separated as the least digestible $(\bar{x}=42 \%)$. Bluebunch wheatgrass was intermediate $(\bar{x}=47 \%)$ in digestibility in 1997, and bottlebrush squirreltail, Thurbers's needlegrass, crested wheatgrass, and basin wildrye were similar $(\bar{x}=53 \%)$ with the highest digestibility values. Between July and September harvest dates, digestibility declined by only $2.3 \%$ in 1997 . In 1998 , regrowth of crested wheatgrass separated as the most digestible $(\bar{x}=$ $46 \%$ ). Bluebunch wheatgrass, bottlebrush squirreltail, Thurber's needlegrass, and basin wildrye were similar and intermediate in digestibility $(\bar{x}=43 \%)$. Although year effects were not analyzed, regrowth digestibility across all effects averaged about $51 \%$ in 1997 and $43 \%$ in 1998 .

Among grazing treatments in 1997, ungrazed herbage and regrowth from vegetative stage grazing were similar and lowest in digestibility (Table 3 ). The phenologically youngest herbage, a product of anthesis grazing, was highest in digestibility. Regrowth of the boot stage treatment was intermediate in digestibility and statistically separate from the other 3 treatments. Although a significant grazing treatment $\times$ harvest date interaction occurred in 1998, separations among treatments illustrated ungrazed herbage was lowest in digestibility; products of vegetative and boot stage grazing treatments were similar (Table 3). Between July and September harvest dates in 1998, herbage digestibility declined by about $7 \%$.

\section{Soil Moisture: Regrowth Herbage Yield Relationships}

We found no significant relationships between postgrazing herbage yields of our grasses and soil moisture content when grasses were grazed. The largest coefficient of determination $\left(R^{2}=0.18, P=0.12\right)$ was with crested wheatgrass. Coefficients of determination among the remaining grasses were all less than 0.10 .

\section{DISCUSSION}

\section{Ungrazed Grasses: Forage Quantity and Quality}

Although cumulative crop year precipitation (347 mm) was 1.5 times greater in 1998 than in 1997, herbage yields among our ungrazed grasses increased only about 30\% compared to 1997. A Great Basin herbage yield model, developed by Sneva and Britton (1983), predicted we would experience a $61 \%$ increase in standing crop in 1998 compared to 1997. Our crop year precipitation accumulation of $205 \%$ of average, however, was well outside of the data range $(40 \%-169 \%)$ used to develop Sneva and Britton's (1983) herbage yield model.

Angell et al. (1990), while researching quality and quantity dynamics of crested wheatgrass, noted standing crop accumulations and crude protein content fell below expectations whenever series of wetter than average years occurred. They speculated soil nitrogen might become limiting when conditions over a series of years foster exceptionally high yields for the environment.

Two patterns persisted during this study which have been observed in other multi-year assessments of forage quality in the region. They were: 1) forage quality declines more rapidly during years of abundant soil moisture than during drier growing seasons, and 2) grasses more readily respond to midgrowing season precipitation with elevated forage quality in drier years than in years with abundant moisture (Hedrick et al. 1969; Ganskopp 1998; Clark et al. 2000; Ganskopp and Bohnert 2001, 2003; Ganskopp et al. 2004). Much of the rapid decline in forage quality during more favorable growing conditions has been attributed to dilution effects caused by a preponderance of low quality reproductive culms (Lamb et al. 2002; Ganskopp et al. 2004). Among ungrazed grasses in this

Table 3. Mean digestibility (percent IVDMD \pm SE) of significant species, grazing treatment, and grazing treatment $\times$ harvest date effects of regrowth from 3 grazed treatments and ungrazed herbage from 6 grasses sampled on 2 dates on the Northern Great Basin Experimental Range near Burns, OR, in 1997 and 1998. Means within a row sharing a common letter are not significantly different $(P>0.05)$.

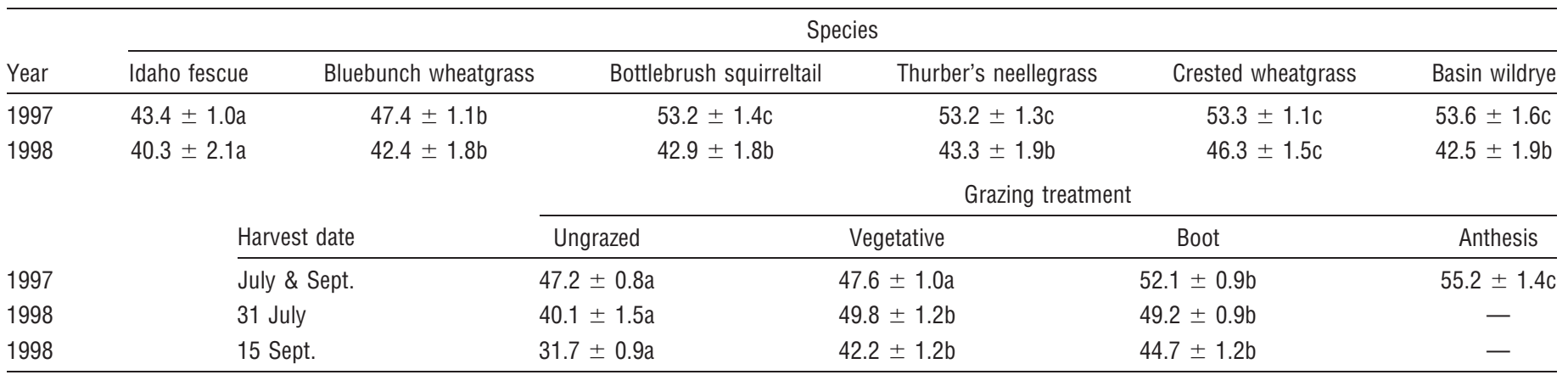


study, reproductive culm counts averaged 47 and 86 per plant, respectively, for 1997 and 1998 (data not shown). Readers are reminded, however, that a mid-season hailstorm damaged much of the reproductive effort in 1997.

Other studies show substantial differences in reproductive efforts of grasses among years. Zhang and Romo (1995) found tiller recruitment positively correlated with soil moisture in northern wheatgrass (Agropyron dasystachyum [Hook.] Scribn.), whereas Hyder and Sneva (1963) reported a greater proportion of crested wheatgrass tillers differentiating with favorable growing conditions, nitrogen additions, or reduced competition. Hyder and Sneva (1963) also noted that crested wheatgrass reproductive culms withered and cured immediately after anthesis, even when soil moisture was sustained via irrigation. We speculate that with more arid growing conditions, fewer culms differentiate. These vegetative culms might grow for several years (Zhang and Romo 1995) and possibly indefinitely under favorable conditions (Hyder and Sneva 1963). We suspect the vegetative culms are responsible for observed spikes in forage quantity and quality that accompany growing season precipitation during drier than average conditions. This hypothesis needs verification for most of our western rangeland grasses with multiyear studies or irrigation supplements to simulate a variety of conditions.

\section{Efficacy of Grazing Treatments: Regrowth Forage Quality}

The disparities in forage quality between years for ungrazed herbage were also reflected in our assessments of regrowth. In 1997, all 3 grazing applications produced regrowth exceeding $7.5 \%$ CP at our 31 July sampling (Table 2). By 15 September, however, $\mathrm{CP}$ concentration from all grazed treatments declined by $2.1 \%-3.5 \%$ to less than $7.5 \%$ CP. At the 15 September sampling, only the anthesis treatment sustained herbage higher in CP than ungrazed tussocks. In 1998, no treatments generated regrowth attaining $7.5 \%$ CP (Table 2). Despite this shortfall, both the vegetative and boot stage treatments did support herbage higher in CP content than ungrazed tussocks on both 31 July and 15 September.

Although CP and IVDMD are only two of several important forage attributes for ruminants, their levels are well correlated with many desirable plant attributes such as vitamin and mineral contents. All of these components typically deteriorate to deficient levels in herbage at about the same time (Sullivan 1962). Although specific requirements vary among ruminants (French et al. 1955; Thorne et al. 1976; Schwartz et al. 1977; Short 1981; Nelson and Leege 1982; NRC 1978, 1981, 1984) even small changes in forage quality that do not reach targeted thresholds, can benefit ungulates accustomed to periodic submaintenance diets (Albon and Langvatn 1992; Clark 1996; Clark et al. 1998). Lastly, most herbivores, through selective grazing, typically harvest diets of higher quality than assays of simulated rations or whole plant samples might suggest (Kiesling et al. 1969; McInnis and Vavra 1987; Cruz and Ganskopp 1998).

\section{MANAGEMENT IMPLICATIONS}

With CP and IVDMD as nutritional indices, ungrazed grasses in this study displayed progressive seasonal declines in forage quality typical of cool season grasses in the region. One can elevate late season forage quality with vegetative, boot stage, or anthesis cattle grazing applications, and one should expect the phenologically youngest regrowth to be higher in $\mathrm{CP}$ and IVDMD at the end of July and mid-September than ungrazed herbage. Our forage conditioning endeavors were more successful in the drier of two growing seasons. We speculate that with wetter growing conditions, a preponderance of tillers differentiate and grazed plants are less likely to generate regrowth. Growing season grazing applications nearly always cause a reduction in end-of-season standing crop among coolseason grasses, and we found grazing treatments affecting late summer/early fall standing crop reductions from $34 \%$ to as much as $100 \%$. Although historical thinking has suggested post grazing regrowth potentials are closely related to soil moisture content when plants were grazed, we found virtually no evidence supporting that hypothesis in this study. Species responses were variable, and bluebunch wheatgrass and crested wheatgrass were more difficult to condition with cattle grazing than other grasses.

Managers applying these grazing management techniques should remember the deleterious effects of boot stage grazing on bunchgrass health. Over the long run, one should consider pasture rotation or deferment programs to sustain plant vigor. Managed cattle grazing of cool season grasses during the growing season can enhance late season forage quality. Those forages can be subsequently used by stockmen to extend animal gain later into the grazing season or reserved for fall or winter use by big game.

\section{LITERATURE CITED}

Albon, S. D., and R. Langvatn. 1992. Plant phenology and the benefits of migration in a temperate ungulate. Oikos 65:502-513.

Anderson, E. W., AND R. J. Scherzinger. 1975. Improving quality of winter forage for elk by cattle grazing. Journal of Range Management 28:120-125.

Angell, R. F., R. F. Miller, and M. R. Haferkamp. 1990. Variability of crude protein in crested wheatgrass at defined stages of phenology. Journal of Range Management 43:186-189.

AOAC. 1990. Official methods of analysis. Volume One. 15th ed. Washington, DC: Association of Official Analytical Chemists. $684 \mathrm{p}$.

ClaRk, P. E. 1996. Use of livestock to improve the quality of elk winter range forage in northeastern Oregon [dissertation]. Corvallis, OR: Oregon State University. $179 \mathrm{p}$.

Clark, P. E., W. C. Krueger, L. D. Bryant, and D. R. Thomas. 1998. Spring defoliation effects on bluebunch wheatgrass: I. winter forage quality. Journal of Range Management 51:519-525.

Clark, P. E., W. C. Krueger, L. D. Bryant, and D. R. Thomas. 2000. Livestock grazing effects on forage quality of elk winter range. Journal of Range Management 53:97-105.

Cody, R. P., And J. K. Smith. 1997. Applied statistics and the SAS programming language. Upper Saddle River, NJ: Prentice Hall. $445 \mathrm{p}$.

Cruz, R., and D. Ganskopp. 1998. Seasonal preferences of steers for prominent northern Great Basin grasses. Journal of Range Management 51:557-565.

FISHER, R. A. 1966. The design of experiments. 8th ed. Edinburgh, Scotland: Oliver and Boyd Ltd. $288 \mathrm{p}$.

French, C. E., L. C. McEwen, N. D. Magruder, R. H. Ingram, and R. W. Swift. 1955. Nutritional requirements of white-tailed deer for growth and antler development. State College, PA: Pennsylvania Agricultural Experiment Station Bulletin, No. 600. 8 p.

GansKoPP, D. 1998. Thurber needlegrass: seasonal defoliation effects on forage quantity and quality. Journal of Range Management 51:276-281. 
Ganskopp, D., And D. Bohnert. 2001. Nutritional dynamics of seven northern Great Basin grasses. Journal of Range Management 54:640-647.

GansKopP, D., AND D. BohneRT. 2003. Mineral concentration dynamics among seven northern Great Basin grasses. Journal of Range Management 56:174-184.

Ganskopp, D., T. Svejcar, and M. Vavra. 2004. Livestock forage conditioning: bluebunch wheatgrass, Idaho fescue, and bottlebrush squirreltail. Journal of Range Management 57:384-392.

Hedrick, D. W., W. M. Moser, A. L. Steininger, and R. A. Long. 1969. Animal performance on crested wheatgrass pastures during May and June, Fort Rock, Oregon. Journal of Range Management 22:277-280.

HobBs, N. T., D. L. BaKeR, G. D. Bear, and D. C. Bowden. 1996. Ungulate grazing in sagebrush grassland: mechanisms of resource competition. Ecological Applications 6:200-217.

Hyder, D. N., AND F. A. SneVA. 1963. Morphological and physiological factors affecting the grazing management of crested wheatgrass. Crop Science 3:267-271.

Kiesling, H. E., A. B. Nelson, and C. H. Herbel. 1969. Chemical composition of tobosa grass collected by hand-plucking and esophageal-fistulated steers. Journal of Range Management 22:155-159.

Lamb, J. B., D. C. Adams, T. J. Klopfenstein, R. J. Grant, P. L. Sims, L. M. White, and S. S. WALleR. 2002. Intake and digestive kinetics of leaf and stem fractions. Journal of Range Management 55:57-64.

LentZ, R. D., AND G. H. Simonson. 1986. A detailed soils inventory and associated vegetation of Squaw Butte Range Experiment Station. Corvallis, OR Agricultural Experiment Station, Oregon State Experiment Station, Oregon State University. Special Report No. 760.184 p.

Mclnnis, M. L., And M. VavRA. 1987. Dietary relationships among feral horses, cattle, and pronghorn in southeastern Oregon. Journal of Range Management 40:60-66.

National Oceanic and Atmospheric Administration (NOAA). 2003. Climatological data annual summary, Oregon. 108:1-36.

Nelson, J. R., And T. A. LeEge. 1982. Nutritional requirements and food habits. In: J. W. Thomas and D. E. Toweill (EDS.). Elk of North America, ecology and management. Harrisburg, PA: Stackpole Books. p 323-367.

NRC. 1978. Nutrient requirements of domestic animals. No. 6. Nutrient requirements of horses. Washington, DC: National Academy of Science, Natural Resource Council. $33 \mathrm{p}$.

NRC. 1981. Nutrient requirements of domestic animals. No. 15. Nutrient requirements of goats. Washington, DC: National Academy of Science, Natural Resource Council. $91 \mathrm{p}$.

NRC. 1984. Nutrient requirements of domestic animals. No. 4. Nutrient requirements of beef cattle. Washington, DC: National Academy of Science, Natural Resource Council. $90 \mathrm{p}$.
Petersen, R. G. 1985. Design and analysis of experiments. New York, NY: Marcel Dekker, Inc. 429 p.

PITT, M. D. 1986. Assessment of spring defoliation to improve fall forage quality of bluebunch wheatgrass (Agropyron spicatum). Journal of Range Management 39:175-181.

Satterthwaite, F. E. 1946. An approximate distribution of estimates of variance components. Biometrics Bulletin 2:110-114.

Schwartz, C. C., J. C. NAGY, AND R. W. RICE. 1977. Pronghorn dietary quality relative to forage availability and other ruminants in Colorado. Journal of Wildlife Management 41:161-168.

SHoRT, H. L. 1981. Nutrition and metabolism. In: 0. C. Wallmo (ED.). Mule and black-tailed deer of North America. Lincoln, NE: University of Nebraska Press. p 99-127.

Skovlin, J. M., P. J. Edgerton, and B. R. McConnell. 1983. Elk use of winter range as affected by cattle grazing, fertilizing, and burning in southeastern Washington. Journal of Range Management 36:184-189.

Sneva, F. A. 1982. Relation of precipitation and temperature with yield of herbaceous plants in eastern Oregon. International Journal of Biometerology 4:263-276.

Sneva, F., and C. M. Britton. 1983. Adjusting and forcasting herbage yields in the Intermountain big sagebrush region of the steppe province. Station Bulletin 659. Corvallis, OR: Agricultural Experiment Station, Oregon State University in cooperation with US Department of Agriculture, Agricultural Research Service. $61 \mathrm{p}$.

Suluivan, J. T. 1962. Evaluation of forage crops by chemical analysis: a critique. Agronomy Journal 54:511-515.

Thorne, E. T., R. E. Dean, and W. G. Hepworth. 1976. Nutrition during gestation in relation to successful reproduction in elk. Journal of Wildlife Management 40:330-335.

Tilley, J. M. A., And R. A. TerRy. 1963. A two-stage technique for the digestion of forage crops. Journal of the British Grassland Society 18:104-111.

USDA, NRCS. 2006. The PLANTS Database. National Plant Data Center, Baton Rouge, LA. Available at: http://plants.usda.gov. Accessed 20 September 2006.

Wambolt, C. L., M. R. Frisina, K. S. Douglass, and H. W. Sherwood. 1997. Grazing effects on nutritional quality of bluebunch wheatgrass for elk. Journal of Range Management 50:503-506.

Westenskow-Wall, K. J., W. C. Krueger, L. D. Bryant, and D. R. Thomas. 1994. Nutrient quality of bluebunch wheatgrass regrowth on elk winter range in relation to defoliation. Journal of Range Management 47:240-244.

Zhang, J., AND J. T. Romo. 1995. Impacts of defoliation on tiller production and survival in northern wheatgrass. Journal of Range Management 48: $115-120$. 